\title{
A Study of Problems and The Reducction Wasted Materials In Coconut Processing of Community Enterprise "Chanmaphowthupsakae" Amphoe Thap Sakae Prachuap Khiri Khan
}

\author{
Supawadee Somsri
}

\begin{abstract}
The study of problems and waste reduction in coconut processing of coconut processing group Amphoe Thap Sakae Prachuap Khiri Khan. Produce processed agricultural products, especially coconut. That can meet the needs of customers. And provide services to meet the needs of customers. Currently many customers are interested in processed coconut products. It is necessary to improve and improve the efficiency to enhance the competitiveness. This research aims to study the problems and reduce the waste in coconut processing. By observation data, query the members of the community enterprise Chanmaphowthupsakae 27 persons. Factors analysis was use to grouping problem. The information obtained from this study leads to the improvement of the coconut processing process for efficient processing. Reduce waste in the process. The improvement of the coconut processing process can reduce the amount of waste from the original $9.40 \%$ after the improvement in the coconut processing. Percentage of waste that occurred after waste improvement was $5.60 \%$.
\end{abstract}

Keywords - Coconut processing, Wastes, Efficacy.

\section{BACKGROUND AND SIGNIFICANCE OF THE RESEARCH PROBLEM}

Coconut is a product of Thai agriculture. With 1,299,799 rai of coconut plantation in the country, it is considered one of the superfoods, making coconut products popular in the world market. As a result, the demand for coconut and coconut products in the global market has increased significantly. And tend to grow well. In the distance all sectors in the economic component have the opportunity to develop and expand their businesses continuously.

Coconut products in Thailand have a strong potential and are very prominent in terms of quality, which are well accepted by the international market and in the private sector, they have developed, processed and developed more packaging models according to market demand. However, at the community level, it is still necessary to receive advice and support from the public and private sectors on product development. The problem is the lack of promotion of minor processing. And industrial processing - promotion of new coconut products. To diversify

Supawadee Somsri, Siam Technology College, 46 Jarunsanitwong10 rd., Thapra branch, Bangkok-yai district, Bangkok 10600 Thailand
Cause waste in many production processes. This results in high production costs. Spoil the opportunity Therefore, the purpose of this study is to Analyze the causes of problems in coconut processing. The coconut processing process was proposed to improve the cost. And to be used as a guide for those interested in the application to continue.

\section{RESEARCH OBJECTIVE}

2.1 To study the problem of waste in coconut processing.

2.2 To explore ways to improve waste reduction in the production process.

\section{SCOPE OF THE STUDY}

This study the coconut processing. To study the problem of waste from coconut processing process of community enterprise. "Chanmaphowthupsakae"

\section{Research Methodology and Collection Data}

The data collected from the following sources:

\subsection{Primary Data}

Data collection using in-depth interviews form Chairman of community enterprise group "Chanmaphowthupsakae". and the observer of making coconuts cause waste.

4.2 Secondary Data

4.2.1. Study of information on waste generated from similar industrial processes from various researches.

4.2.2. Collection of information on the waste that occurred in the coconut processing process before the update. And after the improvement of the process.

\section{DATA ANALYSIS}

The information in the study provides the following guidelines for anaiysis.

5.1 Study of coconut processing process of community enterprises "Chanmaphowthupsakae"

5.2 Study theory and research related to waste reduction in the production process.

5.3 Collect data used to reduce waste in coconut processing.

5.4 Study on the causes of waste in coconut processing.

5.5 Analyze the causes of waste in coconut processing with the operators. 
5.6 Choose ways to improve the reduction of coconut processing waste.

5.7 Summary of performance and recommendations

\section{THE RESULT OF DATA ANALYSIS}

6.1. Collection of waste in coconut processing.

\subsection{Cause Analysis With Fish Bone}

Analysis of the causes of waste in coconut processing. Using fishpond layout as an analytical tool. From the inquiry to the staff at the actual work. And head of production. The problem was solved by using a fish plan, with details and explanations as to why.

6.2.1 Problems caused by the production process of coconut
TABLE I CHARACTERISTICS OF WASTE OCCURRING IN EACH PRODUCTION ACTIVITY.

\begin{tabular}{|c|c|}
\hline $\begin{array}{c}\text { Production } \\
\text { activities }\end{array}$ & Details of waste \\
\hline $\begin{array}{l}\text { 1.Coconut } \\
\text { Scraping Process }\end{array}$ & $\begin{array}{l}\text { Coconut shredded coconut waste was found not to } \\
\text { be able to remove all the coconut shreds. The } \\
\text { fraction of coconut meat that can not be cut into } \\
\text { the shredder accounts for } 6 \% \text { of the amount of } \\
\text { coconuts used in the production per day. }\end{array}$ \\
\hline $\begin{array}{l}\text { 2.Process of } \\
\text { drying coconut }\end{array}$ & No waste found in this process. \\
\hline $\begin{array}{l}\text { 3.Process of } \\
\text { Baking coconut }\end{array}$ & No waste found in this process. \\
\hline $\begin{array}{l}\text { 4.Coconut } \\
\text { Granule Process }\end{array}$ & $\begin{array}{l}\text { Waste from coconut pellets. It is divided into } 2 \\
\text { parts. } \\
\text { 1) The staff of the Measuring coconut to enter } \\
\text { the machine can not enter the coconut machine in } \\
\text { time. Or around the rotating machine. } \\
\text { 2) Caused by the process of measuring coconut. } \\
\text { The employee's projections make the coconut } \\
\text { volume uneven, causing the coconut to be molded } \\
\text { into the coconut too. And too small to be } \\
\text { introduced into the new production process. }\end{array}$ \\
\hline $\begin{array}{l}\text { 5. The process of } \\
\text { Chopped } \\
\text { chocolate }\end{array}$ & $\begin{array}{l}\text { Waste is caused by the chocolate process. As a } \\
\text { result of the Coconut Granule Process, when the } \\
\text { coconut is formed and then plated. Chocolate } \\
\text { Coconut pellets cracked. The manufacturer must } \\
\text { discard it, can not be returned to the production } \\
\text { process. }\end{array}$ \\
\hline $\begin{array}{l}6 \cdot \text { Packaging } \\
\text { process }\end{array}$ & $\begin{array}{l}\text { The waste from the packaging process is divided } \\
\text { into } 2 \text { parts. } \\
\text { 1) In the product packaging process. In the } \\
\text { process of gluing the product box. Glue the other } \\
\text { side of the box to cause damage to the box. } \\
\text { 2) In the packaging process, the crates were not } \\
\text { properly sized. Damage to the product. }\end{array}$ \\
\hline
\end{tabular}

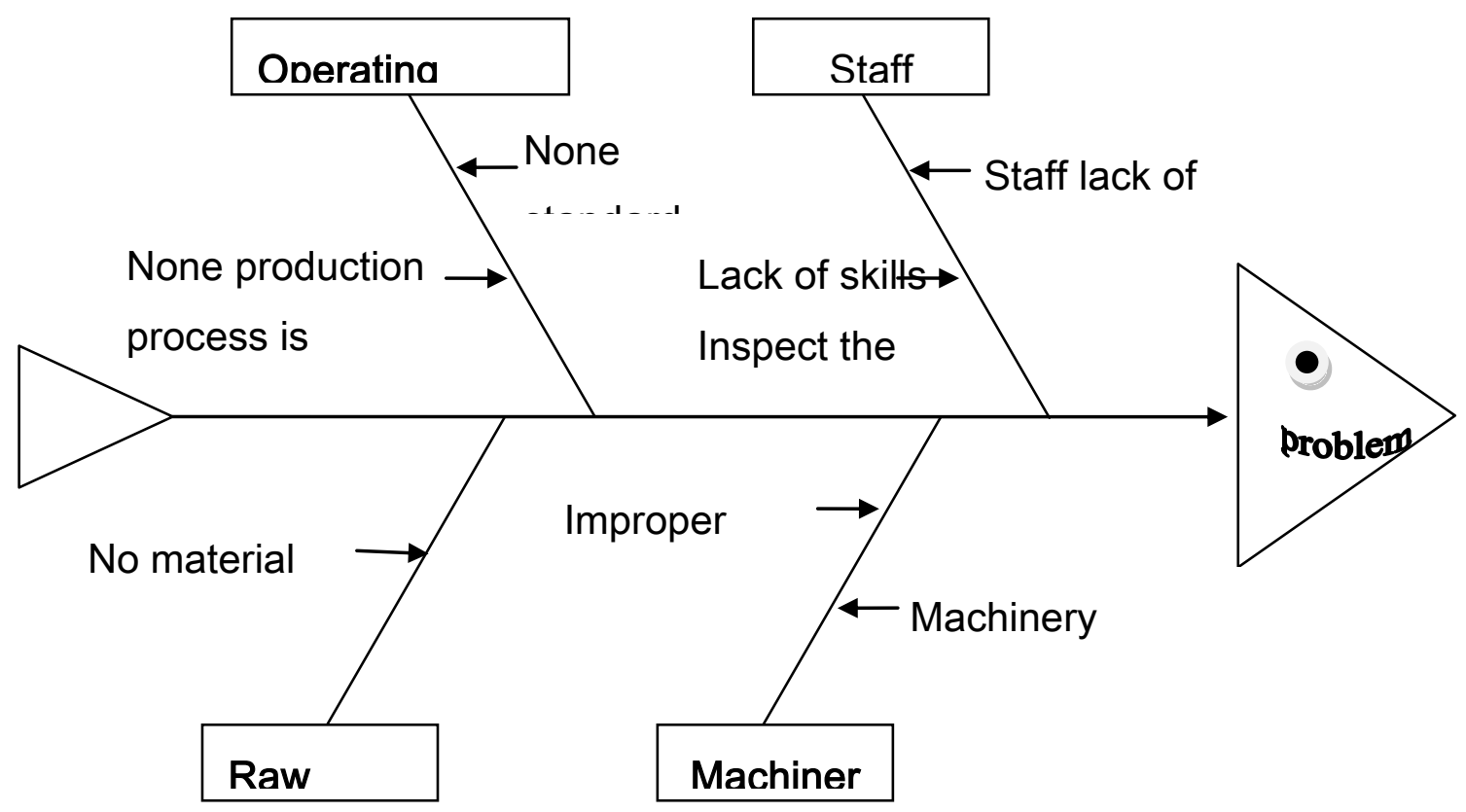

Fig. 1: Problems With The Production Process 
6.3 Solutions to the problem of coconut processing waste. TABLE II GUIDELINES For REDUCTION OF COCONUT PROCESSING WASTE.

\begin{tabular}{|c|c|c|}
\hline category & Cause & solution \\
\hline \multirow[t]{2}{*}{ Staff } & $\begin{array}{l}\text { Staff lack of } \\
\text { empathy }\end{array}$ & $\begin{array}{l}\text { Employees should be aware of } \\
\text { the value of waste that occurs } \\
\text { during the production process. }\end{array}$ \\
\hline & $\begin{array}{l}\text { Lack of skills } \\
\text { Inspect the } \\
\text { workpiece }\end{array}$ & $\begin{array}{l}\text { 1) Should be prepared } \\
\text { operating guide and product } \\
\text { guide } \\
\text { 2) Training should be } \\
\text { provided to employees. Each } \\
\text { department understands the } \\
\text { quality of each product. }\end{array}$ \\
\hline \multirow[t]{2}{*}{$\begin{array}{l}\text { Operating } \\
\text { rocedures }\end{array}$} & $\begin{array}{l}\text { None standard } \\
\text { Clear production }\end{array}$ & $\begin{array}{l}\text { There should be a discussion of } \\
\text { production. And there are clear } \\
\text { procedures. The standard of } \\
\text { performance of each } \\
\text { department is defined. }\end{array}$ \\
\hline & $\begin{array}{l}\text { None production } \\
\text { process is assessed } \\
\text { for each }\end{array}$ & $\begin{array}{l}\text { There should be a discussion of } \\
\text { production. To review the } \\
\text { production process is } \\
\text { complicated. Or review the best } \\
\text { practices in the production } \\
\text { process. }\end{array}$ \\
\hline $\begin{array}{c}\text { Raw } \\
\text { material }\end{array}$ & No material quality & $\begin{array}{l}\text { Identify the standard of raw } \\
\text { materials for employees. The } \\
\text { quality is always checked. }\end{array}$ \\
\hline \multirow[t]{2}{*}{ Machinery } & Improper machine & $\begin{array}{l}\text { Should be provided or } \\
\text { Develop a suitable machine. }\end{array}$ \\
\hline & $\begin{array}{l}\text { Machinery } \\
\text { Deteriorate quickly }\end{array}$ & $\begin{array}{l}\text { Should buy a high-quality } \\
\text { machine. } \\
\text { To reduce the loss. Or reduce } \\
\text { the errors that may occur } \\
\text { during the production process. }\end{array}$ \\
\hline
\end{tabular}

6.4.Measure and compare performance improvement.

After the improvement of the coconut processing process in July, 2017 to

December 2017, it was found that the efficiency of the production process was changed in the process of improvement. The waste in the production process decreased.

TABLE III COMPARISON TABLE NuMBER AND PERCENTAGE OF WASTES INCURRED IN COCONUT PROCESSING BEFORE AND AFTER IMPROVEMENT.

\begin{tabular}{|c|c|c|c|c|}
\hline \multirow{2}{*}{$\begin{array}{c}\text { The nature of the } \\
\text { waste }\end{array}$} & \multicolumn{2}{|c|}{ Before improvement } & \multicolumn{2}{c|}{ After improvement } \\
\cline { 2 - 5 } & Frequency & Percent & Frequency & Percent \\
\hline $\begin{array}{c}\text { Coconut meat can } \\
\text { not be produced. }\end{array}$ & 360 & 6 & 216 & 3.60 \\
\hline $\begin{array}{c}\text { Coconut out of } \\
\text { shape }\end{array}$ & 84 & 1.40 & 24 & 1 \\
\hline Damaged box & 1,200 & 2 & 600 & 1 \\
\hline Total Percentage & \multicolumn{2}{|c|}{$\mathbf{9 . 4 0}$} & \multicolumn{2}{|c|}{$\mathbf{5 . 6 0}$} \\
\hline
\end{tabular}

\section{SUMMARY OPERATING RESUlTS}

A study of reduction of waste from coconut processing. The project manager has studied the solution to reduce the amount of waste in the coconut processing process so that the training, monitoring and monitoring of the work process of the staff closely. Employees are alert. Intended to work more carefully and with more quality. Coconut processing wastes are clearly reduced. The results are as follows.

7.1 Result employees are trained and monitored closely and closely monitored. Intended to work more carefully and with more quality. Coconut processing wastes are clearly reduced. The program is designed to provide efficient processes for the processing and working of employees in the coconut processing process.

7.2 Compare the amount of waste before and after the refurbishment, as a percentage of the amount of waste generated versus the volume of production. The percentages of pre-enriched waste accounted for 9.40 percent after improvements in coconut processing. Percentage of waste that occurred after waste improvement was 5.60\%.

\section{SUGGESTIONS}

8.1 Improve the coconut processing process. It does not affect the quality of the product.

8.2 Training staff involved in the process of coconut processing to understand. It is important to improve the process of processing.

8.3 Provide relevant documentation on steps to improve coconut processing. And quality inspection

\section{REFERENCES}

[1] Jay Heizer and Barry Render (2008), Operations Management, $9^{\text {th }}$ ed., Parso International Educotion.

[2] Single/Individual Warehousing Agreement between Robert Bosch Automotive Technologies.

[3] (Thailand) Company Limited and Kuehne + Nagel Limited, Retrieved March 15, 2016 from

[4] CONTRACT No. W005-8327001, Pluakdaeng, Royong

[5] Tomas u. Ganiron Jr., Nieves Ucol-Ganiron. and Tommy U. Ganiron 111 2017. Recycling of Waste

[6] Coconut Shells as Substitute for Aggregates in Mix Proportioning of Cocrete Hollow Blocks,

[7] New Zealand: World Scientific News 